\title{
Grief, depression, and the DSM-5: a review and reflections upon the debate
}

Peter Zachar*

Every side in the debate about eliminating or retaining the bereavement exclusion for diagnosing major depressive disorder agreed that the DSM-IV was inconsistent. It exempted symptoms of depression from a depressive disorder diagnosis if they were a response to the loss of a loved one, but diagnosed depression symptoms in response to any other kind of loss or stress as a disorder. The participants in the debate did not agree how to resolve the inconsistency — eliminate the exemption for bereavement, leave it in place, or extend it to all cases with loss \& stress-triggered depression symptoms. The difference between how the debate was presented to the general public and the issues debated in the scientific literature is described, as are the facts upon which the various sides readily agreed. Scientific research that casts doubt upon some common assumptions about the psychology of grieving is also reviewed. The article concludes by taking note of both the scientific-empirical and metaphysical facets of the debate, and suggests a pragmatic, verbal solution for one of the metaphysical facets.

Key words: Bereavement, resilience, loss, normality

\footnotetext{
* Auburn University Montgomery (Montgomery, AL, U.S.A.)
} 


\section{Is intense grief a mental disorder?}

During the development of the fifth edition of the Diagnostic and Statistical Manual of Mental Disorders (DSM-5) from 2007 to 2012 many proposed changes were controversial. Some of these controversies caught the eye of the public, others did not. One controversy that certainly did garner public attention was a proposal that would make it easier to diagnose a person in bereavement with a depressive disorder.

One way the proposed change was presented to the public was that psychiatrists intended to declare the normal sadness of grief a mental disorder. This was considered to be a philosophical and scientific mistake. For instance, Allen Frances (2013) claimed that medicalizing grief would reduce the dignity of our reactions to deeply felt losses. His concerns were widely shared.

Truly, we live in an insane world when spouses and children and parents (...) and other grievers around the world can be diagnosed with Major Depressive Disorder- a mental illness- two weeks following a traumatic death at the behest of someone who has no notion of the reality of their experiences. This feels like the apogee of hubris, exorbitant arrogance. Too much knowledge and absolutely no wisdom. (Cacciatore, 2012)

It is a serious matter to propose newly classifying millions of people as psychiatrically disordered who are currently considered normally distressed. It places the very credibility of psychiatry on the line. One would expect such a proposal to be supported by arguments that are precisely formulated and scientifically or conceptually compelling. (Wakefield, 2011, p. 208)

For many opponents of this change, the presumed pathologizing of a normal, healthy response to loss was alarming. Even more alarming to others was the opportunity such a change would offer the pharmaceutical industry. The industry could use large advertising budgets to persuade the 
general public to actively seek medication to "treat" painful feelings that occur in response to the loss of a loved one.

Medicalising grief, so that treatment is legitimised routinely with antidepressants, for example, is not only dangerously simplistic, but also flawed. The evidence base for treating recently bereaved people with standard antidepressant regimens is absent. In many people, grief may be a necessary response to bereavement that should not be suppressed or eliminated. (The Lancet, p. 508)

\section{The debate in the scientific journals}

What entered the public domain did not always reflect the technical debates in the scientific journals. The question for nosologists was not whether to classify normal grief as a mental disorder; rather, it was whether to eliminate the bereavement exclusion in the diagnosis of major depressive disorder. According to the bereavement exclusion, people who meet full criteria for a major depressive episode should not be diagnosed with a depressive disorder if the symptoms represent a reaction to the death of a loved one.

Those who favored eliminating the bereavement exclusion and many of those who favored retaining the exclusion were trying to solve the same inconsistency in the DSM. Depressive episodes often have precipitants. People can lose their job, marriage, health, etc. and become clinically depressed. Of all the losses people experience, the loss of a love one is given special status. Why? What makes bereavement-related depressive reactions different than reactions to other stressors such as divorce and rape? Both sides in the debate agreed that bereavement related losses should not be placed in a special category, but differed on how to solve that problem.

Those who favored eliminating the exclusion for bereavement believed that people at greater risk for depression are more likely to respond to stress and loss with depression. Indeed exposure to stressful life events in the past year is one of the strongest risk factors for the development of depression in general (Kendler, Gardner, \& Prescott, 2002, 2006). In their view, denying treatment to depressed people primarily because they recently experienced one specific type of stressor is not justified - or fair (Pies \& Zisook, 2011; Zisook \& Kendler, 2007; Zisook, Shear, \& Kendler, 2007). They also viewed the exclusion as an anomaly of the $D S M$. It is not, they observed, included in the ICD-10.

Those who favored retaining the bereavement exclusion held that legitimate depressive disorders either occur spontaneously without cause or represent excessive responses that are not in proportion to the stressor (Horwitz \& 
Wakefield, 2007). Depressive feelings during bereavement are normal, but they are also normal in response to other types of stress and loss. Some who favored retaining the exclusion preferred a more radical change in the DSM wherein the exclusion would be extended to cover all cases of triggered depression that were not associated with suicidal ideation, psychomotor retardation, or other highly impairing symptoms (Wakefield, Schmitz, First, \& Horwitz, 2007).

\section{The six week window}

This debate raises interesting and important philosophical questions about when we should normalize distress and dysfunction. There are no easy answers. General clinical wisdom seems to be that the bereavement period can typically last as long as a year, but the $D S M-I V$ allowed depression to be diagnosed once symptoms persisted for longer than two months. Given that symptoms of depression must occur nearly every day, most of the day for two or more weeks, the changes proposed for the $D S M-5$ affected only a brief six week period - after two weeks and before two months.

Parties to the debate agreed that most people do not meet full criteria for depression during bereavement (Kendler, 2010; Wakefield, 2011). They also agreed that those who are experiencing severe symptoms such as suicidal ideation, psychomotor retardation, and marked functional impairment should be diagnosed with a depressive disorder (First, Pies, \& Zisook, 2011). The difficulty was, within the six week window, to distinguish between those in bereavement who meet full criteria for depression but do not have a depressive disorder and those who meet criteria and do have a depressive disorder.

A key worry came down to an expectation that bereavement-related symptoms of depression could be expected to remit on their own in a few months, where a depressive disorder might not remit. The goal was to diagnose only those cases in which the symptoms were less likely to remit on their own.

The problem is an important one, but it may not be specific to bereavement. Indeed, around $40 \%$ of all cases of depression begin to remit on their own in a few months (American Psychiatric Association, 2013; Posternak et al., 2006). To the extent that the bereavement exclusion helps with this prediction, it likely does so because it eliminates from its scope cases with severe symptoms such as suicidal ideation. The culling of highly impairing symptoms rather than excluding symptoms that occur during bereavement may be doing the diagnostic work. 


\section{The grief work assumption}

The bereavement period can be painful and sometimes protracted. Those who favored retaining the exclusion claimed that emotional pain similar to depression in response to the loss of a loved one is a universal human experience.

Nearly 2.5 million Americans die each year, leaving behind an even larger group of grief-stricken people. Such a universal human experience as grief is recognized by the lay public and medical professionals alike as an entirely normal and expected emotional response to loss. Clinicians and researchers have long known that, for the vast majority of people, grief typically runs its course within 2 to 6 months and requires no treatment. (Friedman, 2012, p. 1855)

Less explicitly but arguably part of the background to the intense affect generated in this debate was the grief work assumption. One aspect of this assumption is that that feeling painful emotions related to loss are signs of emotional health whereas not actively processing (even repressing) the painful emotion related to loss may put someone at risk for a pathological, delayed grief reaction. If this is true, eliminating the bereavement exclusion could result in incorrectly classifying healthy responses as mental illness.

No one disputes that grief can be associated with intense emotional pain, but research in scientific psychology disproves the assumption that distress and depression following a loss are universal and inevitable, or that failure to experience distress is a sign of psychopathology (Wortman \& Silver, 1989). In fact, people can have a resilient trajectory to loss in which they develop few or no symptoms of depression and continue to function as before (Zisook, Paulus, Shuchter, \& Judd, 1997). Resilience is also more normal than often thought perhaps characterizing up to $50 \%$ of the population (G. A. Bonanno et al., 2002). There is even evidence that greater mental health is associated with resilience to both loss and severe trauma, and interventions that seek to help those with resilient trajectories process the loss could be iatrogenic (G. Bonanno, 2004; Neimeyer, 2000).

What implication does the research by scientific psychologists have for the debate? As noted, there are people who meet full criteria for depression during bereavement who will recover without an intervention. Such a trajectory may be a normal variation but it is not the norm or even the ideal. Depression following the loss of a loved one is an emotional disruption that compromises functioning. Especially in those cases where recovery will occur with time, treatment may not be necessary, but neither is such a disruption a state of health. 


\section{The DSM-5 resolution}

Despite the opposition, the bereavement exclusion was eliminated in the $D S M-5$. According to the main text of the manual, bereavement induces great suffering, but it does not typically involve a complete major depressive episode. When bereavement and depression do co-occur, functional impairment is more severe and prognosis is worse. The same is true for other stressors such as financial ruin, losses from natural disaster, and serious medical illnesses.

The DSM-IV, of course, contained the exclusion for bereavement, but said little about the relation between affect and emotion in normal bereavement versus bereavement complicated by depression. One of the outcomes of the debate was that this distinction is given a greater explication in the new manual. According to the $D S M-5$, a depressive disorder involves persistent and ongoing depressed mood and lack of all interest in pleasure. In contrast, the emotional disruption in grief occurs in waves, and alternates with positive moods. Also, the sadness of grief is better characterized by feelings of loss and emptiness rather than lack of positive affect. Grief is also directed toward the loss - the feelings are about the deceased person in contrast to the self-critical, inward looking focus of depression.

Still, as Allen Frances (2010) noted based on his own clinical experience, when a case of intense grief meets criteria for a mild depressive disorder, no mental health professional can reliably distinguish between them. This problem raises the difficult topic of the nature of a depressive disorder and the notion of a true depression. Making a distinction between normal bereavement versus "true depression" is empirically and scientifically tractable in some ways, but also metaphysically encumbered in others (Zachar, 2014).

Once we decide how to categorize cases as "bereavement with depressive symptoms" versus "depressive disorder," we can empirically investigate how these categories are similar and different. If "normal" is part of the a priori meaning of bereavement, however, then by definition bereavement is not a psychiatric disorder. This becomes more a matter of metaphysics. One can always adjust the scope of abstract concepts such as "normal" and "disordered" to make them fit a priori assumptions. For example: "Psychomotor retardation is dysfunctional, so when it occurs we not dealing with normal bereavement, but depression;" "People in bereavement often experience loss of appetite, so not eating must be a feature of normal sadness." These are largely verbal claims pertaining to relations between words.

Verbal metaphysical disputes also have verbal resolutions. Rather than trying to distinguish between "normal bereavement with depressive symptoms" and a "true depressive disorder," one can say they are both depression, but normalize the disorder. Patients can be told that it is often normal to develop 
a case of depression in response to the loss of a significant other, but these symptoms often resolve on their own without treatment. People will differ on whether they prefer to seek treatment. That is another normal variation. The important thing is they should be able to choose without being scared into it or promised too much - as pharmaceutical advertisements are inclined to do.

\section{References}

American Psychiatric Association. (2013). Diagnostic and Statistical Manual of Mental Disorders $\left(5^{\text {th }}\right.$ ed.). Washington, DC: American Psychiatric Publishing.

Bonanno, G. (2004). Loss, trauma, and human resilinece. American Psychologist, 59(1), 20-28.

Bonanno, G.A., Wortman, C.B., Lehman, D.R., Tweed, R.G., Haring, M., Sonnega, J., ... Nesse, R.M. (2002). Resilience to loss and chronic grief: A prospective study from preloss to 18-months postloss. Journal of Personality and Social Psychology, 83(5), 1150-1164. doi: 10.1037/0022-3514.83.5.1150.

Cacciatore, J. (2012). DSM-5 and ethical relativism. Retrieved May 26, 2015, 2012, from $<$ http://drjoanne.blogspot.com/2012/03/relativity-applies-to-physics-not.html .

First, M.B., Pies, R.W., Zisook, S. (2011). Depression or bereavement? Defining the distinction. Medscape News: Psychiatry and Mental Health. Retrieved from http:// www.medscape.com/viewarticle/740333.

Frances, A. (2010). Good grief vs major depressive disorder. Psychology Today, (August 21 2010). Retrieved from: <https://www.psychologytoday.com/blog/dsm5-indistress/201008/good-grief-vs-major-depressive-disorder>.

Frances, A. (2013). Saving normal. New York: William Morrow.

Friedman, R.A. (2012). Grief, Depression, and the DSM-5. New England Journal of Medicine, 366(20), 1855-1857.

Horwitz, A.V., Wakefield, J.C. (2007). The loss of sadness: How psychiatry transformed normal sorrow into depressive disorder. New York: Oxford University Press.

Kendler, K.S. (2010). A statement from Kenneth S. Kender, M.D. on the proposal to eliminate the bereavement exclusion for major depression. Retrieved May 29, 2015, 2015, from <http://www.dsm5.org/about/Documents/grief\%20exclusion_Kendler.pdf $>$.

Kendler, K.S., Gardner, C.O., Prescott, C.A. (2002). Toward a comprehensive developmental model for major depression in women. The American Journal of Psychiatry, 159(7), 1133-1145. doi: 10.1176/appi.ajp.159.7.1133.

Kendler, K.S., Gardner, C.O., Prescott, C.A. (2006). Toward a comprehensive developmental model for major depression in men. The American Journal of Psychiatry, 163(1), 115-124. doi: 10.1176/appi.ajp.163.1.115. 
Lancet, The (2012). Living with grief. The Lancet, 379, 589.

Neimeyer, R.A. (2000). Searching for the meaning of meaning: grief therapy and the process of reconstruction. Death Studies, 24(6), 541-558.

Pies, R.W., Zisook, S. (2011). Depression or bereavement? Defining the distinction. Medscape News: Psychiatry and Mental Health. Retrieved from $<$ http://www. medscape.com/viewarticle/740333>.

Posternak, M.A., Solomon, D.A., Leon, A.C., Mueller, T.I., Shea, M. T., Endicott, J., Keller, M.B. (2006). The naturalistic course of unipolar major depression in the absence of somatic therapy. J Nerv Ment Dis, 194(5), 324-329. doi: 10.1097/01. nmd.0000217820.33841.53.

Wakefield, J.C. (2011). Should uncomplicated bereavement-related depression be reclassified as a disorder in the DSM-5. The Journal of Nervous and Mental Disease, 199(3), 203-208.

Wakefield, J.C., Schmitz, M.F., First, M.B., Horwitz, A.V. (2007). Extending the bereavement exclusion for major depression to other losses. Archives of General Psychiatry, 64, 433-440.

Wortman, C.B., Silver, R.C. (1989). The myths of coping with loss. Journal of Consulting and Clinical Psychology, 57(3), 349-357.

Zachar, P. (2014). A metaphysics of psychopathology. Cambridge, MA: The MIT Press.

Zisook, S., Kendler, K.S. (2007). Is bereavement-related depression different than nonbereavement-related depression. Psychological Medicine, 37, 779-794.

Zisook, S., Paulus, M., Shuchter, S.R., Judd, L.L. (1997). The many faces of depression following spousal bereavement. Journal of Affective Disorders, 45(1-2), 85-94. doi: 10.1016/S0165-0327(97)00062-1.

Zisook, S., Shear, K., Kendler, K.S. (2007). Validity of the bereavement exclusion criterion for the diagnosis of major depressive episode. World Psychiatry, 6, 102-107.

\begin{abstract}
(Luto, depressão e o DSM-5: uma revisão e reflexões sobre o debate)

Todos os lados envolvidos no debate sobre a eliminação ou a manutenção do luto como critério de exclusão para o diagnóstico do transtorno depressivo concordavam que o DSM-IV era inconsistente. Nele, sintomas de depressão não contavam para o diagnóstico de um transtorno depressivo se fossem resposta à perda de uma pessoa amada, mas sim em relação a quaisquer outros tipos de perda ou estresse. Os participantes no debate não chegaram a um acordo sobre como resolver a inconsistência - eliminar a cláusula de exceção do luto, mantê-la ou estendê-la a todos os casos com sintomas depressivos precipitados por perda ou estresse. A
\end{abstract}


diferença entre como o debate foi apresentado ao público geral e como os tópicos foram debatidos na literatura científica é descrita, assim como os fatos sobre os quais os vários lados prontamente concordaram. Estudo científico que lança dúvida sobre pressupostos comuns acerca da psicologia do sofrimento do luto também é examinado. Em sua conclusão, o artigo aponta tanto os aspectos científico-empíricos como as facetas metafísicas do debate, e sugere uma solução pragmática e verbal para uma dessas facetas metafisicas.

Palavras-chave: Luto, resiliência, perda, normalidade

(Deuil, dépression et le DSM-5: révision et réflexions sur le débat)

Toutes les parties qui ont participé au débat sur l'élimination ou le maintien du deuil comme critère d'exclusion pour le diagnostic du trouble de la dépression étaient d'accord sur le fait que le DSM-IV était inconsistant, étant donné qu'il n'acceptait pas les symptômes de la dépression liés à la perte d'un proche, mais uniquement ceux liés à tout autre genre de perte ou de stress. Les participants du débat ne se sont pas mis d'accord sur la façon de résoudre l'inconsistance - éliminer l'exception du deuil, la conserver tel quel, ou l'étendre à tous les cas montrant des symptômes de dépression déclenchés par une perte ou par le stress. Cet article décrit la différence entre la façon dont le débat a été présenté au public et les questions discutées par la littérature scientifique, ainsi que les faits sur lesquels les différentes parties se sont mises d'accord. On examine également la recherche scientifique qui met en doute les suppositions courantes sur la psychologie du deuil. Pour conclure, nous mettons en relief les aspects scientifiques-empiriques et les facettes métaphysiques du débat et suggérons une solution pragmatique et verbale pour l'une de ces facettes métaphysiques.

Mots clés: Deuil, résilience, perte, normalité

(El duelo, la depresión y el DSM-5: una revisión y reflexiones acerca del debate)

Todas las partes en el debate acerca de la eliminación o mantenimiento del duelo como criterio de exclusión para el diagnóstico de trastorno depresivo estaban de acuerdo en que el DSM-IV era inconsistente. En él, los síntomas de depresión no contaban para el diagnóstico de un trastorno depresivo si fueran una respuesta a la pérdida de un ser querido, pero se diagnosticaban como trastorno los síntomas depresivos en respuesta a cualquier otra pérdida o el estrés. Los participantes en el debate no estaban de acuerdo sobre la forma de resolver la inconsistencia - eliminar la cláusula de excepción del duelo, mantenerla como estaba, o extenderla a todos los casos con síntomas depresivos precipitados por la pérdida o el estrés. La diferencia entre cómo el debate fue presentado al público general y cómo se trataron los temas de la literatura científica se describe, asi como los hechos en que las diversas partes se pusieran de acuerdo fácilmente. El estudio cientifico que pone en duda 


\section{OBSERVANDO A PSIQUIATRIA}

los supuestos comunes acerca de la psicología del duelo también se examina. En su conclusión, el artículo señala tanto los aspectos científicos y empíricos como los aspectos metafísicos del debate, y sugiere una solución pragmática y verbal a uno de estos aspectos metafisicos.

Palabras clave: Duelo, resiliencia, pérdida, normalidad

(Trauer, Depression und das DSM-5: Revision und Überlegungen zur Diskussion )

Alle Teilnehmer, die an der Diskussion über die Aufhebung oder Beibehaltung der Trauer als Ausschlusskriterium für die Diagnose der depressiven Störung teilnahmen, waren sich einig, dass das DSM-IV inkonsistent war. Das DSM-IV schließt Depressionssymptome für die Erstellung der Diagnose der depressiven Störung aus wenn sie eine Reaktion auf den Verlust eines geliebten Menschen darstellen und akzeptiert sie nur, wenn sie eine Reaktion auf andere Arten von Verlusten oder Stress sind. Die Diskussionsteilnehmer konnten sich nicht darüber einig werden, wie die Inkonsistenz beseitigt werden sollte, d.h., ob man die TrauerAusnahmeklausel beseitigen, ob man sie beibehalten oder ob man sie auf alle Fälle mit Depressionssymptomen als Reaktion auf Verluste oder Stress erweitern sollte. Wir beschreiben die Unterschiede zwischen der Weise wie die Debatte dem Publikum vorgestellt wurde und der Art, wie die Themen in der wissenschaftlichen Literatur beschrieben wurden, sowie die Fakten, die von allen Parteien anerkannt wurden. Wir analysieren außerdem wissenschaftliche Studien, die die allgemeinen Grundsätze der Psychologie der Trauer in Frage stellen. In den Schlussfolgerungen weist der Artikel auf die wissenschaftlichen und empirischen Aspekte, wie auch auf die metaphysischen Aspekte der Debatte hin und schlägt eine pragmatische und verbale Lösung für eine dieser metaphysischen Facetten vor.

Schlüsselwörter: Trauer, Resilienz, Verlust, Normalität

\section{(悲伤，抑有症和DSM-5：辩论回顾与反思）}

争论撤除或保持服丧作为抑郁症的诊断的排除标准的各方都认为DSM-IV 是 不一致的。此认为若抑郁症状与失去亲人有关不该诊断为抑郁症, 但若与其他 失去或压力因素有关即定为抑郁症状。辩论者对此不一致的处理没达成共识 该撤除服丧排除标准、保留它或则扩展到所有失去和压力。本文章呈现该辩论 对一般人的描述和科学文献之间的差异, 以及各方同意的地方。本论文也分析 一项批判心理学对痛苦的一般假设的研究。文章的结论指出无论科学或经验方 面都具有形而上学, 并提出了对于形而上的方面之一的一个务实的和言论的解 决方案。

关键词: 悲伤, 应变能力, 丧失, 正常 
Citação/Citation: Zachar, P. (2015, setembro). Grief, depression, and the DSM-5: a review and reflections upon the debate. Revista Latinoamericana de Psicopatologia Fundamental, $18(3), 540-550$.

Editores do artigo/Editors: Prof. Dr. Claudio E. M. Banzatto e Profa. Dra. Rafaela Zorzanelli

Recebido/Received: 5.6.2015/ 6.5.2015 Aceito/Accepted: 29.6.2015 / 6.29.2015

Copyright: (C) 2009 Associação Universitária de Pesquisa em Psicopatologia Fundamental/ University Association for Research in Fundamental Psychopathology. Este é um artigo de livre acesso, que permite uso irrestrito, distribuição e reprodução em qualquer meio, desde que o autor e a fonte sejam citados / This is an open-access article, which permits unrestricted use, distribution, and reproduction in any medium, provided the original authors and sources are credited.

Financiamento/Funding: $\mathrm{O}$ autor declara não ter sido financiado ou apoiado / The author has no support or funding to report.

Conflito de interesses/Conflict of interest: $\mathrm{O}$ autor declara que não há conflito de interesses / The author has no conflict of interest to declare.

\section{Peter Zachar}

Ph.D. Professor of Psychology. Department of Psychology. Auburn University Montgomery: PO Box 244023

Montgomery, AL. 36124, U.S.A.

e-mail: pzachar@aum.edu 